\title{
Dynamics of Regional Head Elections (Pilkada) in 2020 During the COVID-19 Pandemic
}

\author{
Mudir Johan', Andi Wahyudi ${ }^{2}$ and Irawati Irawati ${ }^{3}$ \\ 1,2,3 Universitas Lancang Kuning, Pekanbaru, Indonesia \\ mudirjohan@gmail.com
}

\begin{abstract}
This research examines the problems of regional head elections (pilkada) as a government system that places the people as the sole voters. Pilkada is defined as the General Election to elect pairs of candidates for Regional Head proposed by a Political Party (Parpol) or a combination of political parties and individuals. But the problem is that the implementation of the pilkada in the COVID-19 pandemic has threatened the health of the people and has an impact on the weakening of various sectors, with this situation several agendas in the process of the pilkada stages were violated by candidate pairs such as not implementing health protocols at every stage of registration so that in the 2020 election feels threatened.
\end{abstract}

Keywords: Local Election (Pilkada); Election Data; COVID-19

\section{Introduction}

Indonesia is a country that upholds democracy, one of the characteristics of a democratic country, namely carrying out elections as a means of selecting leaders. Tricahyo (2009: 6) Election is an instrument of realizing people's sovereignty which has the aim of forming a legitimate government and means of articulating the aspirations of the people's interests, meaning that the Indonesian State involves its people in the framework of state administration, people's sovereignty is carried out by people's representatives who sit in parliament with a system or democracy live. Yandra (2017) added that the demands for resident's residency status to participate in regional head elections become a pivotal thing pursued by KPUD, Regional Government, Political Parties, Panwaslu, Support Tem and the contestant themselves-remember, these efforts are strengthening Consolidated, quality local democracy and civilized. General election is a minimum requirement for democracy which aims to elect people's representatives and regional representatives. People's sovereignty is exercised by representatives of people's representatives who sit in Soedarsono's representative institutions (2005: 1).
Talking about the election cannot be separated from the problems faced by Indonesia at this time, namely COVID-19, the development of the spread of the COVID-19 pandemic outbreak has significantly increased, including Indonesia being the country affected by this pandemic outbreak. Keeping in mind the danger of the outbreak, through the mandate contained in article 12 of the Constitution of the Republic of Indonesia the President then issued a Presidential Decree (Keppres) of the Republic of Indonesia Number 11 of 2020 concerning the Determination of Health Emergencies. Referring to the study of emergency constitutional law, the determination of this emergency is still within the scope of staatsnoodrecht, where the state is required to issue policies to deal with emergency situations (Asshiddiqie, 2012). The implementation of this policy is contained in the application of Large-Scale Social Restrictions in the form of restrictions that have begun to be carried out and calls for avoiding activities that involve large numbers of people are being implemented. Recently, the government issued a policy to ban homecoming to break the chain of spreading the COVID-19 pandemic. 
The government has determined that regional head elections will be held on December 9, 2020. Initially the 2020 pilkada will be held on September 23, 2020, before Indonesia was hit by the COVID 19 pandemic, the General Election Commission (KPU) had carried out a series of stages for the implementation of the 2020 regional elections.

However, due to the COVID-19 pandemic, the KPU finally issued KPU decree no. 179 / PL.02-kpt / 01 / KPU / III / 2020, which regulates the postponement of several stages of the 2020 regional elections, including the inauguration of the Voting Committee (PPS) working period, verification of the support requirements of individual candidates, the formation of Voter Data Update Officers (PPDP) and carrying out matching and research (coklit), as well as updating and compiling voter lists. The postponement of several stages of the aforementioned pilkada can have various impacts in its implementation, both positive and negative. The positive impact, for example, this delay provides space for independent candidates to prepare support requirements as individual candidates. Political parties can also experience relatively relaxation in the recruitment process for regional head candidates.

The problem is that the positive impact is not too significant considering that the deadline for changing the implementation schedule is only three months, from 23 September to 9 December 2020. This change in schedule is considered forced considering that the increase in the number of positive cases of COVID-19 has not sloped and is over. Moreover, until today there is no certainty when this pandemic will end. The impression of coercion over the issuance of Perppu Number 2 of 2020 is indeed visible.

In the context of the 2020 regional head elections, all pilkada actors including organizers, prospective candidates and political parties are fully waiting for the government's response and response regarding the conditions under the Covid-
19 pandemic. By determining the status of a health emergency, limiting interactions complicates movement and hinders the performance of election administrators. Simultaneous voters have entered the stage of determining the Provisional Voters List (DPS) which started from 6-14 September 2020. A total of 2,450,166 voters have been assigned to the DPS (concurrent voter list) spread across 9 districts / cities in Riau province to carry out the 2020 regional elections simultaneously which aims to elect the Governor, Regent and Mayor.

Table 1

Number of Regional Elections

\begin{tabular}{ll}
\hline Governor & 9 \\
Region Leader & 224 \\
City Mayor & 37 \\
\hline
\end{tabular}

\section{Method}

After collecting data, all data collected is then processed. The data were analyzed using qualitative methods, namely by thoroughly describing the data obtained during the research process. Miles and Huberman in Sugiyono (2012: 246) reveal that in qualitative data processing through stages of reduction, data presentation, and drawing conclusions.

a. Reduction

Reducing means summarizing, choosing the main and important things then looking for themes and patterns (Sugiyono: 2012: 247). At this stage the researcher sorts out which information is relevant to the research. It is less and leads to the core of the problem so that it can provide a clearer picture of the object of research.

b. Presentation of data

Presentation of data in qualitative research is descriptive text. Information obtained in the field is presented in the best possible text, without any additions that are not adjusted to existing facts. This aims to be able to present the data that has been reduced correctly and the actual situation in the field. 
c. Drawing conclusions at the final stage of data processing is drawing conclusions. After all the data are presented the problems that are the object of the research can be understood and then conclusions are drawn which are the results of this research. d. Media tracking

\section{Results and Discussion}

\subsection{Local Election (Pilkada)}

General Election for Regional Heads and Deputy Regional Heads or commonly referred to as Pilkada or Pemilukada is a General Election to elect pairs of candidates for Regional Head proposed by a Political Party (Parpol) or a combination of political parties and individuals. Pilkada (Regional Head Election) is an election conducted directly by residents of the local administrative area who have met the requirements. In Indonesia, currently regional head elections can be conducted directly by residents of local administrative areas who have met the requirements.

Purwoko (2005: 100) in direct regional elections, existing democracy means opening up opportunities for every citizen to hold public office, it also means that there is an opportunity for the people to use their political rights directly and the opportunity to make choices and participate in controlling the running of the government.

Regional head elections can also be carried out in a joint package with the deputy regional head. The said regional heads and deputy regional heads include the following:

a. Governor and deputy governor for the province

b. Regent and deputy regent for the district

c. The mayor and deputy mayor for the city

The election of governors, regents and mayors in the midst of the COVID-19 pandemic is certainly not easy. Besides having to ensure the technical aspects related to the election, Bawaslu must also control aspects of the COVID-19 health protocol which are the safety standards for election organizers. Technical aspects, namely all matters relating to election governance which can be categorically divided into 3 major groups, namely pre election period, election period, and post election period. For example, in the early period, namely the preparation of the legal framework, schedule, budget, outreach, and voter data collection. The election period includes nominations, campaigns, campaign funds, voting, recapitulation, and determination of candidate voters. Meanwhile, the post election period is evaluation and recommendation preparation.

In the election atmosphere at the time of the COVID-19 pandemic, the health aspect or anticipating organizers and voters not being exposed to the COVID-19 virus becomes an additional task that must be ensured as a consequence of the policy of holding elections. This aspect relates to the compliance of the organizers and the parties involved in the selection of the health as safety protocol.

\subsection{Postponement of the 2020 regional elections}

As a result of the COVID-19 pandemic, the General Election Commission issued a policy of postponing several stages of implementing simultaneous regional elections for 2020. There are about 3 stages that are postponed, namely the inauguration of the voting committee (PPS), verification of prospective individual candidates and recruitment of voter data updating officers (PPDP) and matching and research (coklit) of voter data.

Provincial KPU establishes a post to request reports and complaints on voter data, publish and disseminate information on updating voter data to the public. Compile a mapping of the vulnerability of voter data, namely the vulnerability of the density of voters in border areas, vulnerable 
voters, the COVID-19 red zone, the problem of recording electronic ID cards etc. Supervision of the stages of voter list verification is essential to ensure citizens who qualify as registered voters in the voter list for the elections. In addition, it also ensures that the determination of the voter list is in accordance with the provisions of statutory regulations. In the context of anticipating COVID-19, the KPU has implemented health protocols by carrying hand sanitizers, wearing masks, and previously carrying out rapid tests to ensure that they are free from the COVID-19 virus.

The Riau Provincial KPU will also prepare a special TPS for COVID-19 patients and still be able to exercise their voting rights in the 2020 elections. Special polling stations are prepared around hospitals that treat COVID-19 patients while patients who are independently isolated at home will be visited at home. the. Officers will pick up balls to patients who are positive for COVID-19. If the patient is in a condition that it is not possible to vote on his own, the user of his / her right to vote will be represented by a trusted person or a member of the polling committee. The 2020 regional elections will be held in 270 regions throughout Indonesia amid the real exposure of the COVID-19 pandemic.

For Riau province, the local elections will be held in 9 districts / cities, namely Bengkalis, Dumai, Indragiri Hulu, Kuantan Singingi, Meranti Islands, Pelalawan, Rokan Hilir, Siak, and Rokan Hulu with a total of 8,400 polling stations.

Details of the number of voter lists in 9 Regencies / Cities in Riau Province starting from the highest order:

Table 2

Details of The Number of Voters

\begin{tabular}{cc}
\hline Region/City & Number of Voters \\
\hline Rokan Hilir & 398,656 \\
Bengkalis & 381,347 \\
Rokan Hulu & 323,277 \\
Indragiri Hilir & 291,573 \\
Siak & 267,188 \\
Kuantan Singingi & 230,832 \\
Pelalawan & 214,368 \\
Dumai & 204,060 \\
Kepulauan Meranti & 138,865
\end{tabular}

Based on the table, the largest number of voters is in Rokan Hilir Regency, namely 398,656 people, in Bengkalis with 381,347 people, Rokan Hulu with 323,277 people, Indragiri Downstream 291,573 people, Siak 267,188 people, Kuantan Singingi 230,832, Pelalawan 214,368 people, Dumai 204,060 people, and the smallest number is in the Meranti Islands with 138,865 voters.
Pilkada during the pandemic was between substandi or procedural democracy.

\section{Conclusion}

Based on the above explanation, the 2020 simultaneous regional elections during the COVID-19 pandemic were held in 270 regions in Indonesia, especially in Riau Province which was held in 9 Regencies / Cities namely Bengkalis, Dumai, Indragiri Hulu, Kuantan Singingi, Meranti Islands, 
Pelalawan, Rokan Hilir, Siak, Rokan Hulu with 8,400 TPS.

To anticipate COVID-19, the KPU has implemented a health protocol by carrying a hand sanitizer, wearing a mask, and previously carrying out a rapid test to ensure it is free from the COVID-19 virus. The KPU must serve positive COVID-19 patients in the regional elections. Voting organizers (KPPS) officers will visit residents who cannot come to the polling stations so they can still exercise their voting rights. They must exercise their voting rights, because one vote is very valuable in determining the progress of a region

\section{References}

Kaase, M., \& Marsh, A. (1979). Political action: A theoretical perspective. Political action: Mass participation in five western democracies, 27-56.

KPU RIAU, Laporan Kegiatan Tahapan Pemilu Tahun 2019. Laporan Hasil Pemilu 2014

Nie, N. H., Verba, S., \& Kim, J. O. (1974). Political participation and the life cycle. Comparative Politics, 6(3), 319-340.

Nugroho, N.S., (2015). Partisipasi Pemilih Warga Negara Rokan Hulu:Studi Kasus Pemilihan DPRD Kabupaten dan Pemilihan Presiden tahun 2014. Robinson, J. P., Shaver, P. R., \& Wrightsman, L. S. (1999). Measures of political attitudes. Academic Press.

Yandra, A. (2017). Penyelamatan Hak Pilih Warga Perbatasan Jelang Pilkada. POLITIK, 13(1). 